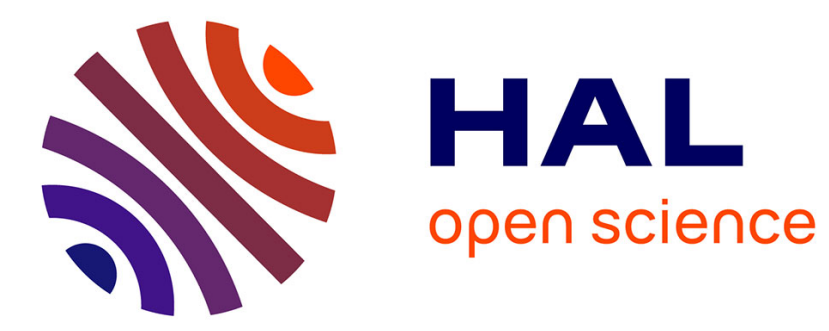

\title{
Pierre Smith's mind traps: The origin and ramifications of a theory of ritual efficacy
}

\author{
Arnaud Halloy
}

\section{To cite this version:}

Arnaud Halloy. Pierre Smith's mind traps: The origin and ramifications of a theory of ritual efficacy. Anthropological Theory, 2015, 15 (3), pp.358 - 374. 10.1177/1463499615594559 . hal-01797240

\section{HAL Id: hal-01797240 \\ https://hal.science/hal-01797240}

Submitted on 2 May 2019

HAL is a multi-disciplinary open access archive for the deposit and dissemination of scientific research documents, whether they are published or not. The documents may come from teaching and research institutions in France or abroad, or from public or private research centers.
L'archive ouverte pluridisciplinaire HAL, est destinée au dépôt et à la diffusion de documents scientifiques de niveau recherche, publiés ou non, émanant des établissements d'enseignement et de recherche français ou étrangers, des laboratoires publics ou privés. 
Pierre Smith's mind traps: The origin and ramifications of a theory of ritual efficacy

\author{
Arnaud Halloy \\ LAPCOS - University of Nice, France
}

2015, Vol. 15(3) 358-374

(C) The Author(s) 2015

Reprints and permissions: sagepub.co.uk/journalsPermissions.nav DOI: I0.II77//4634996/5594559 ant.sagepub.com @SAGE

\begin{abstract}
The Belgian anthropologist Pierre Smith was a perceptive ethnographer and a forwardthinking theorist whose insights provided the fertile ground out of which grew influential anthropological approaches to ritual, ritual efficacy, and art some 30 years later. In this article, I trace the genealogy of the 'mind trap', a key concept in Smith's theoretical writing and a true analytical gem in itself. The appeal of Pierre Smith's theory lies with how ritual action (or art) might produce such entrapment of the mind, and why this might be a key process in ritual (and art) efficacy, i.e. 'operations' liable to trigger a transformation. I then go on to review the many reverberations and ramifications of his concept as reflected in two recent theoretical approaches to ritual and ritual efficacy, as well as the possible connections between Smith's 'mind trap' and certain aspects of Alfred Gell's anthropological theory of art. Pierre Smith points ethnographers and ritual theorists in the right direction to answer questions about the transformational nature of many rituals (and art works) around the world. While mind traps cannot fully explain ritual efficacy, they can serve as a starting point for a strong and ethnographicallygrounded theory of ritual efficacy.
\end{abstract}

\title{
Keywords
}

cognition, Alfred Gell, mind trap, ritual efficacy, Pierre Smith

\section{Introduction}

How do rituals work? What do they do to people and how do they do it? With his concept of mind trap, Pierre Smith offers some possible ways to answer these questions and at the same time outlines a tentative theory of ritual efficacy whose

Corresponding author:

Arnaud Halloy, University of Nice Sophia-Antipolis, LAPCOS-ISHSN-SJA3 3, Bd. François Mitterrand, Nice, 06537, France.

Email: arnaud.halloy@gmail.com 
influence can be traced in a series of recent anthropological approaches to ritual, ritual efficacy, and arts. In this paper, my aim is neither to tackle theoretically the problem of ritual efficacy, nor to trace back its history. Instead, I simply claim that a ritual or 'ritualized action' (Bell, 1992; Humphrey and Laidlaw, 1994) is effective when it does what it purports to do: healing a patient in a shamanic ritual, cleansing or bestowing grace in a religious ceremony, incorporating a Spirit in a possession cult or extracting it from the body in an exorcism, making a boy into a man in a male initiation, etc. Efficacy, as opposed to the effects of social rules or norms, cannot be reduced to a mere social convention. Efficacy is, by its very nature, transformational (Sax, 2004). We can therefore say of a ritual or ritualized action that it is effective when it actually transforms the people that take part in it, i.e. when it changes not only how they are perceived by others, but also the way they think and feel about themselves and the world.

Here, I will first come back to, and give an in-depth account of the concept of 'mind trap' as it was developed by Pierre Smith in his 1979 and 1984 articles, and later - even if rather marginally - in his 1997 article. I will then go on to review the many echoes and ramifications of his concept as reflected in a series of contemporary theories of ritual, ritual efficacy, and arts.

The concept of 'mind trap" appeared for the first time in 'Aspects de l'organisation des rites' ['Aspects of the Organization of Rites'] - certainly, Pierre Smith's most cited work - published in 1979 [1982] in an edited volume, a tribute to Claude Lévi-Strauss. It was, however, in a different article, published in 1984 in L'Homme, that he would attempt to both theoretically refine his concept and to put it to the test against new ethnographic data. ${ }^{2}$ Yet he never gave a univocal definition of the concept. Rather, he used it quite literally to mean a form of action that can actually entrap the mind. All the appeal of Pierre Smith's theory, as I will try to show, lies with how ritual action (or art) might produce such an entrapment of the mind, and why this might be a key process in ritual (and art) efficacy, i.e. 'operations' liable to trigger a transformation. In a nutshell, mind traps literally entrap the mind; they confuse it by generating uncertainty and ambiguity - uncertainty about incompatible interpretations and ambiguity about one's own attitude towards it. And they produce such specific cognitive effects, as I will analyse in greater detail, because ritual action (and its relational patterns) in most mind traps tends to refer back to itself and to merge form and content, action and reference, cause and representation, performance and identity.

Today, we can identify at least three anthropological approaches to ritual and art influenced by the 'mind trap': (1) the French pragmatic or relational approach to ritual; (2) the cognitive or cognitivist approach to ritual; and (3) the possible connections between Smith's 'mind trap' and certain aspects of Alfred Gell's theory of art. Among the supporters of the first approach, Michael Houseman and Carlo Severi are, in my view, two of the main heirs and successors to several of Smith's theoretical insights regarding the nature of ritual facts. From the beginning, the 'mind trap' equally inspired quite a few 'cognitivist' anthropologists, among them Pascal Boyer whose first book, an analysis of the oral epics of the Fang in 
Cameroon and Gabon, was published in 1988 under the title Barricades mystérieuses et pièges à pensée. Finally, it is difficult, if only more speculative, not to detect a trace of Pierre Smith's 'mind trap' in several texts by Alfred Gell, such as his 'Vogel's Net: Traps as Artworks and Artworks as Traps' (2006 [1996]) and his posthumous book, Art and Agency (1998), particularly the chapter entitled 'The Critique of the Index', an analysis of decorative patterns as 'traps for seeing' (Severi, 2011). To my knowledge, Alfred Gell never cited Pierre Smith, but he did read and cite Pascal Boyer's book (1988), particularly in 'Vogel's Net'. In any case, however indirect the Belgian anthropologist's influence on Gell's new theory of art might be, it does not make it less significant.

Let us now start with an account of the origin of Pierre Smith's concept and then watch it grow into a fully-fledged theory of ritual efficacy.

\section{'Mind traps': From the concept to the theory of ritual efficacy}

The concept of 'mind trap' first appeared in Pierre Smith's 1979 article. Smith's original approach to the ritual consists of an articulation between, on the one hand, the so-called 'kernel of rituals' [noyau des rites], made of a series of 'focalizing elements' around which the content of the ritual is organized, and, on the other hand, the form that contains them, namely the place that the ritual in question holds within a larger liturgical whole or 'ritual system'. In the ways in which he unpacks the concept of ritual, Smith seems less concerned with deciphering its alleged meaning and more interested in exploring the mystery of its 'incredible complexity and captivating strangeness' (1982 [1979]: 103). In doing so, Smith deems it essential to be able to move away from the social and/or symbolic interpretations of ritual, as he clearly states it:

If we admit that the kernel of rituals lies less in the translation of a mythology, a vision of the world, or a symbolism than in their encounter with what I would call a certain type of 'snare for thought' [piège à pensée], many of the questions traditionally posed by anthropologists and historians of religions will appear ill-conceived. (1982 [1979]: 106)

Therefore, it seems that the concept of 'mind trap' was meant primarily as an attempt to break away from previous accounts of the ritual as a 'display of social mechanisms', a 'faithful reflection of the myths' or even more 'a confused forest of diversely associated symbols' (Smith, 1982 [1979]). ${ }^{3}$ The notion of 'snare' or 'trap', which lies at the heart of the theory that he will later develop, points to two insights: first, in terms of ritual efficacy, that the action and the effects that action is likely to have on the mind ${ }^{4}$ come first, and secondly, that the nature of ritual action is intrinsically ludic and/or reflexive. Here is how Smith himself envisages the relationship between the mind and ritual action:

... that thought devoted to ritual activities lets itself be caught in this way in the trap laid for it, which in the end is its own trap. (1982 [1979]: 105) 
Ritual efficacy, i.e. the power of ritual to do what it purports to do, does not actually reside in 'the absence or presence of reference to religious belief or worship' but in 'the absence or presence of a simulation, an operation whose supposed efficacy is simulated' (Smith, 1982 [1979]: 104). Now, there would be no simulation without the ritual actors' willingness to play the game, whatever the game might involve: masks, sacrifice, prayer, initiation or trance (Smith, 1982 [1979]: 110). Therefore, ritual efficacy depends first and foremost on an 'attitude' - a recurring term in his 1979 article - defined as 'taking the rituals seriously without giving them too much credence' (Smith, 1982 [1979]: 104). ${ }^{5}$

To illustrate his propositions, Pierre Smith takes the example of the bullroarer, an item widely used in male initiation rituals all over the world, which he calls, not without a hint of provocation, 'a prehistoric gadget' or an 'aural mask'. ${ }^{6}$ While other anthropologists and folklorists were busy putting forward 'arbitrarily borrowed or reconstructed' competing interpretations of 'the ultimate or original signification' (Smith, 1982 [1979]: 109) of the rites and ritual objects ${ }^{7}$ they were researching, Pierre Smith suggested that, on the contrary, the rite should be stripped of its mythological and interpretative contexts. Once the stripping was done, the researcher could focus analysis on the effects on ritual action of the insertion of the bullroarer into that particular ritual and of its use. Furthermore, the analysis would draw on the object's 'own features', such as its aural qualities (its continuous throbbing sound), its shape, the possibilities but also the risks of handling it, etc.

With his 'Aspects of the Organization of Rites' (1982 [1979]), Pierre Smith set the stage for, or rather laid the foundations of, what was to become a theory of ritual or, more precisely, a theory of how rituals work, what they do to people, and how they do it. For this was his ambition, or at least his aspiration. In this article, Smith focused on the comparison of two ritual systems (one of the Bedik in Senegal and the other of Swazi royal rites in Rwanda), all the while questioning and testing the anthropological theories that were supposed to account for the two systems and trying to put his finger on the 'abstract schema' or 'the very principles' of the organization and efficacy of rituals. What he aimed for was the study of ritual in itself and for itself as advocated by Lévi-Strauss (1981 [1971]). However, it would not be until 'Le "Mystère" et ses masques chez les Bedik' that he would outgrow the concept of 'snare for thought' or 'mind trap" ${ }^{8}$ and go on to develop a fully-fledged theory of ritual efficacy.

Published in 1984, in L'Homme, this essay is dedicated in its entirety to the masks and ritual technologies that support the ritual of 'Mystere' among the Bedik, a population living in the southwestern-most part of Senegal. Smith's article opens with a definition of the 'mind trap' as he understands it at this point, i.e. 'the focalizing elements around which the various sequences of the rite are structured' (1984: 5). ${ }^{9}$

According to Smith, these are 'operations whose purported effects are simulated or reflected by the agents' (1984: 5). Therefore, his notion of 'mind trap' refers to a unique and, as his 1979 article had already announced, an intrinsically reflexive 
manner of organizing and performing ritual action. The novelty in this 1984 definition is that these actions retain an autotelic or auto-referential dimension: the range of their meanings invariably points back to the actions themselves. In other words, ritual meaning and perceived efficacy are directly experienced and enacted from and through ritual action itself. This is especially true in the case of the Bedik, who are ever so reluctant to allow any interpretation of the elements of their ritual action because the ritual action itself is deemed to guarantee ritual efficacy. ${ }^{10}$ And it is this type of 'paradoxical technology' that enables the use of 'mind traps' as tools or, to use Smith's terminology, 'operations' liable to trigger a transformation such as the one expected in the context of an initiation ritual, for instance - or even to reveal the existence of and to make one experience the presence of spirits, e.g. one's ancestors or spirits of the bush:

I find that this type of technology allows one to see beyond its more abstract, internalized and hidden nature and right into the heart of the genuine ritual operation which always involves some degree of simulation experienced as magic. (1984: 5, emphasis added)

The end of this quote, 'simulation experienced as magic', holds the whole richness of the concept. This is an invitation - in the spirit of Latourian 'factish' gods (1996) or of Michel Leiris's 'lived theatre' (1958) - to overcome the rigid and simplistic right - wrong, authentic - simulated dichotomies in order to defend the idea that the efficacy of 'genuine"11 ritual action depends on a form of organization of action where simulation makes things true, and where facts can only be revealed through mystification. Let us now develop this idea - which stands far out of our comfort zone, to say the least - starting with the case of the Bedik masks and Pierre Smith's (1984) superb account of it.

In his analysis of the 'Mysterre' of the Bedik masks, as he translated the local term Usyl, Smith distinguishes between at least two types of individuals who engage directly with 'mind traps': on the one hand, the non-initiated audience among them women - who allow themselves to be misled; and, on the other hand, the initiated wearing masks, "who feel and claim to be invested with a sacred mission that puts them in closer contact with the invisible powers' (1984: 5). In addition to these basic social categories, there are more general ones, the man/woman, bush/village or even nature/culture oppositions, and more specific ones, such as different age groups within the category of the initiated (Gabail, 2012), the distinction between spirits and ancestors, etc. All adding to the richness, but also to the complexity of the way each individual relates to the 'Mystère'. But, as Smith rightly points out, it is above all the reflected nature of the secret that makes up the efficacy of the 'mind trap':

Usyl [Mystère] is something that you do, with each participant knowing how it works for their part but not being supposed to know how it works for the others, and of which you do not speak. (1984: 16) 
Therefore, the power or efficacy of 'Mystère' seems to rely on the two-fold action of the 'mind trap'. In cognitive terms, the secret seems to be not so much about content, given that people know very well how to do their own part, but more about the impossibility of knowing the thing in itself, of which you do not speak and which can only refer back to itself as in the autotelic nature of ritual mentioned earlier. In relational terms, it is each participant's attitude towards the secret, as reflected by the others' attitude towards it, that seems to be the source of the ambiguity and, consequently, of the potential reality of the secret. To put it differently, according to Pierre Smith, the reality of the secret depends on the adjustment of mutually constitutive positions: ${ }^{12}$

The holding in place of the Mystere, on which the entire customary system depends, requires however the complicity of women who make up its audience. It is because of the women's apparent belief in it that men do not conceive of themselves as mere actors in a sham but, quite to the contrary, they feel truly invested with a mysterious role granted to the future generations by their ancestors. (1984: 17)

As a result, the mind traps seem to help maintain a so-called form of epistemological and/or ontological uncertainty (Halloy and Servais, 2014; Losonczy and Cappo, 2013) in relation to the 'Mystere' and the world of supernatural beings (spirits, ancestors). This uncertainty as to the very nature of what is and what is represented - incompatible interpretations - would be contingent on the staging of the spirits' presence and the dissonant attitude that the audience and actors project back and forth between them. An aspect of this contrastive attitude worth mentioning is sensory discrepancy, with the women focusing more on the aural aspects (the bullroarers, the hurling of stones on the roofs, the drumming, etc.) while the men mobilize all their senses (sight, touch, smell, kinesthetics), as in the wearing of plant masks, techniques of the body, of the voice, etc. In any case, the contrastive attitude is enacted and embodied in these so-called 'paradoxical technologies' which are supposed to cultivate doubt and ambiguity as to the nature of things rather than to univocally assert one meaning over others. As Smith noted, while men 'admit it openly, and often with a sense of humor, that the Usyl ['Mysterre'] helps them dominate the women', every time they pass by a mound of stones of the kind you find all over Bedik territory, allegedly the tombs of men 'killed and cursed for having breached the rules that protect the staging of $U s y l$ against the curiosity of women', they place a stone on top of it to ward off misfortunes (1984: 20). Therefore, the mystification is not to be taken lightly and it is to be maintained against all odds, for the interplay of attitudes exchanged by the actors and beneficiaries of the many stagings of the 'Mystere' makes it possible for this ritual to exist, to be re-asserted and its presence experienced:

The entire system ultimately relies on the simulation by both parties of a mystification whose efficacy we presume in order to render it more evocative. (Smith, 1984: 32, emphasis added) 
In other words, the trap owes its efficacy to being revealed. Furthermore, the efficacy of the trap is born out of an evocative process that, instead of a clear and exact meaning, aims at keeping the inferential process idle, at having the mind slip and fall into the trap that was set for it - what Mattijs van de Port would call the impossibility of a 'symbolic closure' (Van de Port, 2011). A way to achieve that, and a powerful way for that matter, is the autotelic nature of ritual, which does not need to refer to something other than itself and plays on the divisions between simulation and non-simulation or dissimulation and disclosure of the secret.

This approach to ritual action resonates with several contemporary theories of ritual. For some authors of these theories, affiliation with Pierre Smith is explicit. For others, it seems to be less apparent. Among the authors who more or less acknowledge their affiliation with Smith, I will discuss three contemporary theorists of ritual: Michael Houseman, Carlo Severi and Pascal Boyer. Alfred Gell, as we will see, never cited Pierre Smith's work, but their theoretical filiation seems hard to contest.

\section{'Mind traps': Contemporary ramifications of a theory of ritual efficacy}

The theoretical influence of Pierre Smith and his mind traps is visible to varying extents in the works of all the authors mentioned above, and his ideas are relevant today. In this second section of the article, I do not aim to provide an objective summary of the authors who have included the concept of 'mind traps' in their tool kit but rather to point to several contemporary theorists of ritual who openly admit to be Smith's followers or at least to have drawn inspiration from his work to a certain extent.

Unmistakably, the spectre of Pierre Smith and his mind traps haunts the seminal theory of ritual that grew out of Michael Houseman and Carlo Severi's fascinating Naven or the Other Self (1998 [1994]), revisiting Gregory Bateson's Naven (1936). In this important book, Houseman and Severi aim to develop a new approach to ritualization understood as a 'particular mode of action':

This is not defined by its functional properties or by any syntactic characteristics (for example, repetition or fragmentation), or by qualities depending on pragmatic considerations (performativity, staging procedures), but primarily on the establishment of a particular type of relational configuration. (1998 [1994]: 262)

Within this relational framework, the two anthropologists identify a recurrent trait of ritual organization - a 'kernel of the ritual' [noyau du rite] - which they call 'ritual condensation'. Starting from their analysis of the Naven, a transvestism ceremony performed by the Iatmul of Papua New Guinea following a first-time cultural achievement by an individual, ${ }^{13}$ they have shown that ritual relations are often depicted by the simultaneous enactment of ritual behaviours and attitudes 
normally considered mutually exclusive, that is, the condensation of roles and relations (1998 [1994]: 196-7), e.g. the show of authority and of subordination at the same time, the presence of people or other beings that is both denied and affirmed, secrets that are both disclosed and hidden, etc.

In Houseman and Severi's description of ritual condensation, we identify the elements of a 'mind trap' in its own right. First, they focus on the way ritual action is organized, i.e. the 'relational form' specific to the ritual (Houseman and Severi, 1998 [1994]) rather than on ritual symbolism. Second, they emphasize the reflected nature of the dissonant attitudes and relations that are enacted by ritual condensation, guiding the ritual actors, especially the laua (honoured through the ritual), in self-defining and redefining social positions in relation to the wau's (initiator of the ritual) behaviour towards them. And last, what better way to trigger uncertainty in the ritual beneficiary as to the nature of what is being performed or represented than by means of transvestism, the form of simulation par excellence?

In this connection, Carlo Severi makes the best use of the concept of ritual condensation by showing that the efficacy of Native American shamanic rituals is due to a large extent to the shaman's capacity to become a 'complex enunciator', i.e. 'a unique and unexpected kind of enunciator, constituted by a series of connotations which simultaneously point to both the allied and the enemy spirits, the plants and the animals, the seer spirit represented by the Balsa Tree and the Jaguar of the Sky' (2007: 222). In so doing, Severi goes against the Lévi-Straussian view of the effectiveness of symbols and adopts an analytic framework much more in sync with the idea of the mind trap. Indeed, in his now famous article on the effectiveness of symbols, Lévi-Strauss (1963 [1949]) describes how a Cuna (a South American Indian population) shaman cures a woman going through a difficult childbirth. Lévi-Strauss claims that the shamanic chanting works as a means of expressing the unspeakably intense pain of the woman in a new language made possible by the right symbolism. In other words, the pain becomes expressible as symbol due to a series of images provided by the chanting, which, to some extent, 'embody' the story of the woman's experience. This identification process would then enable the woman to exercise conscious control over her own experience: the order of the symbol working as an indispensable primer for the physiological order. What Severi shows using his concept of 'complex enunciator' is that the efficacy of the shamanic chanting relies less on the woman in labour embodying a predefined cultural symbolism than on the creation of a specific context of enunciation, in this case the condensation of mutually exclusive identities in the person of the shaman (2002: 37; 2007).

More recently, I was pleased to identify the influence of Pierre Smith's mind trap in at least three special issues of three different anthropology journals: first, the 2002 issue of Social Anthropology dedicated to ritual reflexivity; second, the 2011 issue of Gradhiva, whose editor-in-chief is Carlo Severi, with the title Pièges à voir, pièges à penser [Traps for Seeing and Thinking]; and the 2012 issue of $H A U$. Journal of Ethnographic Theory dedicated to 'relational uncertainty'. ${ }^{14}$ 
Among the authors of the Social Anthropology issue, Michael Houseman is undoubtedly the author whose ideas are most in sync with Pierre Smith's. Just like Smith in his 1979 article, Houseman (2002) attempts to single out the 'kernel of the ritual' by comparing in detail two different ritual systems: (1) the male initiation rites of the Gbaya Kara of the Central African Republic and the so ritual of animal sacrifice of the Beti of Southern Cameroon. He looks for the ritual kernel in what he calls the 'pragmatic conditions' of the rite, namely the 'interactive pattern' liable to trigger or at least to guide the participants' performance and understanding of the ritual situations. Houseman's analysis of Gbaya Kara male initiation rites and Pierre Smith's 'mind trap' have at least two points in common: (1) actors entering a pattern of mutually constitutive relations, and (2) the uncertain nature of the knowledge produced by such relational patterns. As a result, the novice's experience and understanding of his own situation mainly rely on the attitude that he is provided with by his initiators, as well as by his mother and the uninitiated (Houseman, 2002: 83). Now, as the author clearly shows, all the actors, the mothers, the uninitiated and the novices themselves are aware that their respective understandings of the alleged 'death' of the novices is incomplete and that some part of the initiation mystery is beyond their grasp. All the actors are equally aware that they perform a role meant to deceive the others as to the true nature of their own involvement and of the performance itself. This is to say that, apart from the initiators, nobody knows for sure what the real stake of the performance is. This 'eminently reflexive [...] state of mind regarding not only the nature of the novices' "death" but also the status of their own actions in it' (2002: 82) is the very definition of Houseman's concept of 'dissimulation'.

With the so ritual of animal sacrifice, Houseman singles out yet another kernel of the ritual. In addition to dissimulation, which is an 'illusion centered around the manipulation of people' (2002: 88), Houseman identifies a second principle, 'simulation', which relies on the manipulation of 'non-persons' such as objects, animals, spells, images, etc. The principle of simulation applies, first of all, to the initiators, i.e. the individuals who are fully aware of the simulated nature of the acts they perform. The initiator who sacrifices the animal for the so ritual knows the secret that makes the animal silent during the slaughtering. ${ }^{15}$ How are we then to account for this initiator's (real) commitment to the rite? In other words, what is the source of efficacy in the case of an apparently simulated Mystere?

Houseman (2002) identifies two 'focalizing elements' - as Pierre Smith would call them. The first one works towards the merging of causality and representation that define an action or discourse. This process, or mind trap, was well described by Pascal Boyer (1990) in his analysis of Fang divination practices - as I will show. Here we see Houseman (2002) expanding its scope and using it to account for the so ritual, or even further, for ritual initiation in general. In Houseman's two case studies, ritual practices both communicate the representations of a transformation the transformation of male children into adults and, owing to the intervention of invisible entities, the transformation of a domestic animal into a goat-skin bag 
containing the 'so fat', a magical substance - and provide the conditions necessary for achieving this presumed transformation. We should note, however, that the type of mind trap used in the Beti so ritual proves to be not so much integrative see particularly Turner's condensation of symbols ${ }^{16}$ - as conflationist. By this I mean that it tends to blur the ontological boundaries between the categories of entities it uses and to manipulate rather than integrate them all in a meaningful whole.

The second process consists of the participants' entering an 'auto-referential circuit' within the ritual sacrifice, which includes both the essential fact of the goat's silence as it is sacrificed and the eating of 'so fat' by the novices, fat that comes from previous sacrifices performed by the initiators or their predecessors. In other words, the sacrifice comes full circle and grants the initiators - and future initiates - special status, which enables them to achieve what the ritual purports to achieve, by having them enter 'auto-referential trajectories in which relations of causality and representation converge' (Houseman, 2002: 88).

I now move on to two cognitive approaches in anthropology that bear the mark of Smith's 'mind traps'.

In his first book, Pascal Boyer focuses on what grants Fang epic poems (mvët) their cognitive salience, i.e. what makes them appealing, and 'stick in the mind', as Pierre Smith would have it (Smith, 1984: 5). According to Boyer, this process takes the form of "paradoxical statements [which] help to build a thinking device whose effect is that the more you try to disentangle yourself from it, the more entangled you become' (1988: 41, my translation). As a matter of fact, mvët performances by Fang bards do confuse or trap the mind by a systematic use of oxymoronic obscure allusions, an accumulation of Baroque details and confusing or contradictory statements. By mixing up two kinds of themes - the lyrical, where the bard's life and experiences are depicted, and narrative passages relying on epic poems - Fang bards also conflate performance and reputation, and suggest to the audience a double interpretation of what is being revealed during mvët performances. In other words, the very nature of mvët performances prevents them from revealing their content in a univocal manner. But the ambiguity goes beyond the performance per se. Fang bards are themselves seen as 'pseudo-sorcerers' or 'pseudo-healers' - in an ambiguous relationship with secrecy, witchcraft or ghosts. The recipients of the communications thus come to presuppose that these utterances hold a meaning yet to be accessed, and most of the time beyond their reach.

This social 'contamination' helps reinforce the authority of those who transmit the paradoxical statements and at the same time makes the paradoxes appealing for the mind. We can identify here the auto-referential nature of ritual action as described by Pierre Smith, as well as the circular nature typical of facts of tradition: tradition relies on a form of communication where content and manner of transmission overlap (Boyer, 1990; Déléage, 2009; Halloy, 2010). This is a constitutive feature of the mind trap, the seed that will later grow into a fully-fledged debate 
about the nature and significance of religious concepts and contexts in the transmission of religion in general (Boyer, 2001; Barrett, 2004; Atran, 2002; Houseman, 2004; Norenzayan et al., 2006).

And now last, but by no means least, I reach the case that illustrates the influence of Smith's mind traps on Alfred Gell's theory of art. Gell, to my knowledge, has never cited Pierre Smith. However, as I will try to show, in Gell's theory of art there are to be found traces of Pierre Smith's 'mind traps' at their most 'cognitivist', so to speak.

Gell's theory is built on the (seminal) idea that what we usually call 'art' is a manifestation of agency and that different modes of realization of artistic material are connected to different ways of manifesting, detecting and reacting to agency. According to this line of thought, art objects are peculiarly 'difficult' objects:

They are difficult to make, difficult to 'think', difficult to transact. They fascinate, compel, and entrap as well as delight the spectator. Their peculiarity, their intransigence, and oddness is a key factor in their efficacy as social instruments. (Gell, 1998: 24)

Artworks and certain art techniques can thus be described as genuine 'psychological weapons' (1998: 69) imbued with a type of 'agency which is essentially indecipherable' (Gell, 1998: 71). And it is precisely because works of art are good at 'entrapping the onlooker in their thought-process' (1998: 253) that they can be considered mind traps. Gell is explicit about his definition of the 'mind-trap' when he comments on what he calls 'complex decorative patterns': ${ }^{17}$

So in fact we just mentally resign ourselves to just not quite understanding these complex relationships, we write them in as 'beyond our ken'. We experience this as a kind of pleasurable frustration, we are drawn into the pattern and held inside it, impaled, as it were, on its bristling hooks and spines. This pattern is a mind-trap (cf. Gell, 1996). We are hooked, and this causes us to relate in a certain way with the artefact which the pattern embellishes. (1998: 80)

This effect of entrapment may thus range from mere 'frustrated admiration' (Stoichiță, 2009: 23) to complete fascination or 'enchantment' (Halloy and Servais, 2014) ${ }^{18}$ But in all cases, it arises from a 'blockage' in cognition caused by the 'captivating' and 'capturing' of attention. To conclude, Gell suggests that art, or 'technologies of enchantment' (1992) in general, should be understood as 'mind-traps' likely to create blurry areas in cognition, where such dichotomies as the real and the imagined, the outside and the inside, the true and the simulated overlap until they almost merge.

We are here at the very heart of Pierre Smith's characterization of mind traps as epistemological uncertainty, but also as a configuration of dissonant attitudes or points of view resulting in, let's say, a consented (cognitive) entrapment. Nonetheless, Gell has never mentioned Pierre Smith's work and, to my knowledge, he never refers to Smith's or Boyer's 'pièges à pensée' in his Art and Agency 
(1998), but cites his own 'Vogel's Net' instead. ${ }^{19}$ Gell must have been familiar with Boyer's Barricades mystérieuses et pièges à pensée (1988) since he cites it, particularly in 'Vogel's Net', whose subtitle reads 'Traps as Artworks and Artworks as Traps'. Pointing out Alfred Gell's theoretical indebtedness to Pierre Smith does not devalue Gell's own contribution to the understanding of artworks and rituals. Even if Gell lost the referential source of one of his seminal ideas along the way, it is obvious that he went much further than Pierre Smith in application as well as in the description of the cognitive processes at work in the differentiated qualities of mind traps he identified in artworks and other 'technologies of enchantment'.

\section{Conclusion}

In the introductory chapter of The Problem of Ritual Efficacy, William Sax rightly points out that, according to Catherine Bell (1992) and many other theorists, rituals or ritualized actions produce the kind of 'ritualized agents' they produce 'not by means of representations but rather through embodied practice' (Sax et al., 2010: 8). Embodied practice, as he further suggests, appears as a cornerstone of ritual efficacy, considering that rituals, "with their emphasis on sensory experience (prescribed bodily postures, music, dance, incense, food, etc.) work primarily on the body and not exclusively by cognitive means' (2010: 8 ). If we were to agree with Sax on the importance of embodiment processes in ritual efficacy, I would see two critical challenges raised by this approach. First, it is crucial not to reify the age-old body/mind dualism. Splitting the 'body' from 'cognitive means' makes it hard if not impossible to explain how the use of senses produces cognitive effects and how cognitive processes affect our experience of the senses. In other words, 'embodied cognition' remains a black box in relation to how perception and cognition work together to actually transform people in situations such as rituals. A second challenge for thinking ritual efficacy through an embodiment approach is how to account for the constitutive role of contextual factors in cognition, i.e. how specific environments (e.g. specific contexts of enunciation; Severi, 2007) frame mind/body interaction in specific ways. Many ritual theorists convincingly show that ritual actions are special, that they differ from other types of action. Roy Rappaport $(1979,1999)$, for example, identifies what he calls the obvious aspects of rituals, i.e. the most apparent features that lead us to identify events as instances of rituals (1979: 173). Rappaport, among others (Humphrey and Laidlaw, 1994; Liénard and Boyer, 2006; McCauley and Lawson, 2002 ; Halloy, 2012; Naumescu, 2012), shows how a set of recurrent patterns of ritual features might play a central role in the framing of cognitive, perceptual, and emotional processes observed in ritual contexts.

Pierre Smith's mind traps insightfully resolve both challenges as they emphasize the importance of the form of action in ritual efficacy and describe what ritual action potentially does to the mind. Mind traps literally entrap the mind; they confuse it by generating uncertainty and ambiguity - uncertainty about incompatible 
interpretations and ambiguity about one's own attitude towards them, some kind of a consented entrapment. At the very heart of Pierre Smith's characterization of mind traps, form and content, action and reference, cause and representation, performance and identity tend to be merged, revealing their autotelic (ritual action referring back to itself) and conflationist nature. As I hope to have shown in this paper, mind traps are polymorphic in nature. Even if they share common traits, they might differ from one cultural context to another, and we could say their outmost limit is the very limit of human imaginative work in creating technologies of enchantment - or the opposite of that. ${ }^{20}$

Using ritual as an example, Pierre Smith points ethnographers and ritual theorists in the right direction to explore the transformational nature of many rituals (and art works) around the world. While mind traps cannot fully explain ritual efficacy, they can serve as a starting point for a strong and ethnographicallygrounded theory of ritual efficacy.

\section{Acknowledgements}

The author wishes to warmly thank Ioana Miruna Voiculescu for her translation work, as well as Laurent Gabail, the editors, and two anonymous reviewers of Anthropological Theory for their valuable comments on a previous version of this paper.

\section{Notes}

1. Pièges à pensée in the original. In his 1982 translation of Pierre Smith's Aspects de l'organisation des rites, John Leavitt chooses to translate piège à pensée as 'snare for thought'. However, for the purpose of this article, I choose to translate piège à pensée as 'mind trap' to emphasize the cognitive/cognitivist understanding of the concept [translator's note].

2. Smith also mentions 'mind traps' briefly in the introduction to his 1997 article published in L'Homme, but the richest account of the concept is to be found in his 1984 article.

3. It couldn't be more obvious to which classic book on the anthropology of ritual he is referring.

4. Smith's preference for 'la pensée' - translated as mind-over belief is a first indication of his interest in cognitive processes and their unique relation to ritual action. This choice also shows his willingness to move away from an interpretation of ritual efficacy based on belief.

5. This could be construed as a 'performative' counterpart to Octave Mannoni's famous phrase: 'I know but still...' (1969 [1963]).

6. Aural masks are present in many West African initiation societies. In most cases, they use the sound of a wide range of instruments (bullroarer, flute, horn, friction drum, etc.) or voice modulation techniques in order to embody the aural presence of invisible entities in persons or environments. Among the Minyanka (Jespers, 1995, 2001, 2014), for example, women are strictly forbidden to see the masks. After being confined in an enclosed space, women will only experience the presence of spirits or ancestors through the sounds they produce around the hut. Such sensory discrepancy between men and women in relation to masks and ancestors is a constitutive element of the mind trap capable of enhancing the kind of uncanny and potentially dangerous presence of masks and ancestors seen among the Minyanka. 
7. In particular, Pierre Smith discusses the psychoanalytical interpretation of the folklorist Dundes (1976), who viewed the bullroarer as a 'flatulent phallus' and associated it with the initiates being reconceived (the phallic aspect) and reborn (the anal aspect) by their male initiators.

8. Certainly because of Alfred Gell's influence, 'mind trap' seems to me to be a better translation of 'piège à pensée' than 'snare for thought', the equivalent used in the 1982 English translation of Pierre Smith's 1979 article.

9. He does the same for his 1997 article.

10. 'The names of celebrations, of spirits that are embodied there, of the altars, etc., they all generally refer only to their own occurrence in the ritual cycle' (Smith, 1984: 7).

11. According to Pierre Smith (1979), what makes a ritual 'real' is its capacity to produce one or more beliefs in the individuals who participate in it.

12. As Laurent Gabail rightly pointed out to me, this idea is a reflection of Andras Zempléni's first paper (1976) on the secret, which he defines not as content but rather as an interaction pattern - or as the process of 'secretion'. Zempléni himself was most probably inspired by Georg Simmel's paper 'The Sociology of Secrecy and of Secret Societies' (1906).

13. Such as performed by the maternal uncle in honour of his uterine nephew upon the latter's return from his first head-hunt. It should be noted, however, that under the Naven many other cognate and affine relations can be enacted, and there are also much more spontaneous and less elaborated versions of the Naven used to celebrate less important achievements (Houseman and Severi, 1994).

14. I will not come back to these papers in the space of this paper. Among the contributions that follow in the tradition of Pierre Smith's 'mind traps', I recommend to the reader Laurent Gabail's (2012 ) remarkable analysis of initiation relations of the Bassari in Guinea.

15. They drug the animal by adding certain herbs to its food.

16. Victor Turner considered that unifying symbols contained separate meanings brought together either in fact through ritual action, or in thought (1967: 28). From this perspective, ritual is conceived of as a manipulation of symbols.

17. A complex decorative pattern can be obtained through the multidimensional orientation of a single motif, as in the example of a Greek key decorative pattern analysed by Gell (1998: 79). As a result, 'we perceive it simultaneously as a texture and as an arrangement of shapes (but precisely what arrangement is harder to say)' (1998: 79).

18. Gell himself uses the notion of enchantment, particularly in his 1992 article.

19. In a paper published in L'Homme in 2009, Victor Alexandru Stoichiţă also makes a direct connection between Smith's 'mind-traps', Pascal Boyer's book mentioned earlier, and Alfred Gell's general theory of art.

20. As, for example, the psychological entrapment of witchcraft (Favret-Saada, 1980; Bonhomme, 2012) or actual use of mental torture against prisoners of war.

\section{References}

Atran S (2002) In Gods We Trust: The Evolutionary Landscape of Religion. New York: Oxford University Press.

Barrett J (2004) Why Would Anyone Believe in God? Lanham, MD: Altamira Press.

Bell D (1992) Ritual Theory, Ritual Practice. New-York: Oxford University Press.

Bloch M (1974) Symbols, song, dance and features of articulation: Is religion an extreme form of traditional authority? European Journal of Sociology 15: 55-81. 
Bloch M (2012) Anthropology and the Cognitive Challenge: New Departures in Anthropology. Cambridge: Cambridge University Press.

Bonhomme J (2012) The dangers of anonymity: Witchcraft, rumor, and modernity in Africa. HAU Journal of Ethnographic Theory 2(2): 205-233.

Boyer $\mathrm{P}$ (1988) Barricades mystérieuses et pièges à pensée. Introduction à l'analyse des épopées Fang. Nanterre: Société d'Ethnologie.

Boyer P (1990) Tradition as Truth and Communication: A Cognitive Description of Traditional Discourse. New York: Cambridge University Press.

Boyer P (1997) La religion comme phénomène naturel. Paris: Bayard.

Boyer P (2001) Et l'homme créa les dieux. Comment expliquer la religion. Paris: Robert Laffont.

Déléage P (2009 L'épistémologie des savoirs traditionnels. In: L'animisme parmi nous. Paris: PUF, 147-154.

Dundes A (1976) A psychoanalytic study of bullroarer. Man 11(2): 220-238.

Favret-Saada J (1980) Deadly Words: Witchcraft in the Bocage. Cambridge: Cambridge University Press.

Gabail L (2012) Performing opacity. Initiation and ritual interactions across the ages among the Bassari of Guinea. HAU, Journal of Ethnographic Theory 2(2): 138-162.

Gell A (1998) Art and Agency: An Anthropological Theory. Oxford: Clarendon.

Gell A (2006 [1992]) The technology of enchantment and the enchantment of technology. In: The Art of Anthropology: Essays and Diagrams. Oxford: Berg, pp. 159-186.

Gell A (2006 [1996]) Vogel's net: Traps as artworks and artworks as traps. In: The Art of Anthropology: Essays and Diagrams. Oxford: Berg, pp. 187-214.

Halloy A (2010) 'Chez nous, le sang règne!' Transmettre la tradition dans le culte Xangô de Recife (Brésil). Terrain 55: 10-27.

Halloy A (2012) Gods in the flesh: Outline of an emotional learning process in the Xangô possession cult (Recife, Brazil). Ethnos: Journal of Anthropology 77(2): 177-202.

Halloy A and Servais V (2014) Enchanting Gods and dolphins: A cross-cultural analysis of uncanny encounters. Ethos: Journal of the American Society for Psychological Anthropology 42(4): 479-504.

Houseman M (2002) Dissimulation and simulation as forms of religious reflexivity. Social Anthropology 10(1): 77-89.

Houseman M (2004) Vers une psychologie de la pratique rituelle? Critique 680-681: 102-144.

Houseman M and Severi C (1994) Naven ou le donner de voir. Essai d'interprétation de l'action rituelle. Paris: CNRS, Chemins de l'Ethnologie.

Houseman M and Severi C (1998) Naven, or, The Other Self: A Relational Approach to Ritual Action. Leiden: Brill.

Humphrey C and Laidlaw J (1994) The Archetypal Actions of Ritual: A Theory of Ritual Illustrated by the Jain Rite of Worship. Oxford: Clarendon Press.

Izard M (2002) Pierre Smith (1939-2001). L'Homme 161: 7-14.

Jespers P (1995) Le masque et la parole. Analyse d'un masque 'auditif' de la société initiatique du Komo Minyanka, Mali. In: de Heusch L (ed.) Objets-signes d'Afrique. Tervuren: Musée royal de l'Afrique centrale, pp. 37-56.

Jespers P (2001) La puissance du masque: De l'audible au visible. In: Badir S and Parret H (eds) Puissances de la voix: Corps sentant, corde sensible. Limoges: Presses universitaires de Limoges, pp. 51-69.

Jespers P (2014) L'ouverture des yeux au Komo. Analyse d'un rite d'agrégation dans une confrérie du Komo en pays Minyanka. In: Bouttiaux A-M (ed.) La dynamique des 
masques en Afrique Occidentale. Tervuren: Musée Royal de l'Afrique Centrale, Studies in Social Sciences and Humanities 176: 37-66.

Latour B (1996) Petite réflexion sur le culte moderne des dieux faitiches. Paris: Les empêcheurs de penser en rond. Synthélabo.

Leiris M (1958) La possession et ses aspects théâtraux chez les éthipiens de Gondar. Paris: Plon.

Lévi-Strauss C (1949) L'efficacité symbolique. Revue de l'histoire des religions 135(1): 5-27.

Lévi-Strauss C (1963) The effectiveness of symbols. In: Structural Anthropology, Vol. 1, trans. Jacobson C and Graundfest Schoepf B. New York: Basic Books, pp.186-206.

Lévi-Strauss C (1971) Mythologiques IV: l'homme nu. Paris: Plon.

Lévi-Strauss C (1981) Mythologiques IV: The Naked Man, trans. Weightman J and Weightman D. New York: Harper \& Row.

Liénard P and Boyer P (2006) Whence collective rituals? A cultural selection model of ritualized behavior. American Anthropologist 108(4): 814-827.

Losonczy A-M and Cappo SM (2013) Ritualized misunderstanding between uncertainty, agreement and rupture: Communication patterns in Euro-American Ayahuasca ritual interactions. In: Labate $\mathrm{BC}$ and Cavnar CA (eds) The Expansion and Reinvention of Ayahuasca Shamanism. Oxford: Oxford University Press.

McCauley N and Lawson T (2002) Bringing Ritual to Mind. Psychological Foundations of Cultural Forms. Cambridge: Cambridge University Press.

Mannoni O (1969 [1963]) 'Je sais bien, mais quand même...'? Clefs pour l'imaginaire ou l'Autre Scène. Paris: Seuil. coll. 'Points'.

Naumescu V (2012) Learning the 'science of feelings': Religious tin Eastern Christian monasticism. Ethnos: Journal of Anthropology 77(2): 227-251.

Norenzayan A, Atran S, Faulkner J and Schaller M (2006) Memory and mystery: The cultural selection of minimally counterintuitive narratives. Cognitive Science 30: 531-53.

Rappaport R (1979) The obvious aspects of ritual. In: Ecology, Meaning and Ritual. Berkeley, CA: Atlantic Books, pp. 173-221.

Rappaport R (1999) Ritual and Religion in the Making of Humanity. Cambridge: Cambridge University Press.

Sax WS (2004) Healing rituals: A critical performative approach. Anthropology and Medicine 11(3): 293-306.

Sax WS, Quack J and Weinhold J (eds) (2010) The Problem of Ritual Efficacy. Oxford: Oxford University Press.

Severi C (2002) Memory, reflexivity and belief: Reflections on the ritual use of language. Social Anthropology 10(1): 23-40.

Severi C (2007) Le principe de la chimère. Une anthropologie de la mémoire. Paris: Musée du Quai Branly.

Severi C (ed.) (2011) Pièges à voir, pièges à penser. Présences cachées dans l'image. Gradhiva, Vol 13.

Simmel G (1906) The sociology of secrecy and of secret societies. The American Journal of Sociology 11(4): 441-498.

Smith P (1979) Aspects de l'organisation des rites. In: La Fonction symbolique. Essais d'anthropologie réunis par Michel Izard and Pierre Smith. Paris: Gallimard.

Smith P (1979) Avant-propos. In: La Fonction symbolique. Essais d'anthropologie réunis par Michel Izard and Pierre Smith. Paris: Gallimard. 
Smith P (1982) Aspects of the organization of rites. In: Izard M and Smith P (eds) Between Belief and Transgression: Structuralist Essays in Religion, History and Myth, trans. Leavitt J. Chicago: University of Chicago Press.

Smith P (1984) Le 'Mystère' et ses masques chez les Bedik. L'Homme 24(3-4): 5-33.

Smith P (1997) Les tambours du silence. L'Homme 143: 151-163.

Stoichiță VA (2009) Pensée motivique et pièges à pensée. Musique, tissage et œufs de Pâques en Moldavie. L'Homme 192(4): 23-38.

Turner V (1967) The Forest of Symbols: Aspects of Ndembu Rituals. Ithaca, NY: Cornell University Press.

Van de Port M (2011) Ecstatic Encounters: Bahian Candomble and the Quest for the Really Real. Amsterdam: Amsterdam University Press.

Zempléni A (1976) La chaîne du secret. Nouvelle revue de psychoanalyse 14: 313-324.

Arnaud Halloy is a Belgian anthropologist, Assistant Professor at the University of Nice Sophia Antipolis (France) since 2007. He graduated in Anthropology at the Free University of Brussels (Belgium) and he received his PhD in 2005 from the Ecole des Hautes Etudes en Sciences Sociales (Paris-France). After studying an Afro-Brazilian cult in Belgium during his graduation, he travelled to Brazil where he conducted extensive fieldwork in the Afro-Brazilian Xangô Possession Cult of Recife, in the North-East Region of Brazil. Arnaud Halloy's main interest lies in the mutual influence between contextual and cognitive dimensions of religious transmission, exploring the tight links between cognition, emotion, perception and cultural environments. He is now focusing his research on emotions senses, and their specific role in possession learning process, oracular systems, "empowerment" of artefacts, and "traditional" transmission. He emphasizes the necessity of a closer collaboration between cognitive and social sciences in order to elaborate a cognitive ethnography of cultural learning. 